that created two years ago by the far less formidable experiments of $\mathrm{Mr}$. Edison in the same direction.

The material which Mr. Swan proposes to render incandescent by means of an electric current is a "wire" of prepared carbon of extraordinary density and elasticity. Twenty years ago he prepared carbon filaments for the very same purpose from calcined cardboard, in. closing them in a glass vessel from which the air was withdrawn as perfectly as the imperfect air-pumps of that date permitted. In October 1877 , or one year before Mr. Edison had begun to attempt the construction of lamps with carbonised paper, Mr. Swan had some prepared carbons mounted in glass globes and exhausted by the Sprengel air-pump by Mr. Stearn of Birkenhead. This enabled Mr. Swan to discover that when the carbon was properly fixed and heated during exhaustion so that the occluded gases might be expelled, there was an end of the causes that hitherto had seemed to defeat all attempts to utilise this method of procuring an incandescent electric light; for when these conditions were observed there was none of the disintegration of the carbon rods, nor of the blackening of the globes that with less perfect vacua had proved the ruin of carbon lamps. The filaments of carbon now produced by Mr. Swan indeed resemble steel wire rather than carbon, so extraordinary is their tenacity and texture. The secret of their manufacture has not yet been made known, being the essential point of the patent rights which Mr. Swan has just secured. Each filament is about three inches long, and not more than the hundredth of an inch in diameter, and is so slight as only to weigh from one-fifteenth to onetwentieth of a grain. The durability of these filaments is remarkable. In the course of a lecture delivered on November 25 last before the Society of Telegraph Engineers, Mr. Swan stated that he had had lamps lighted continuously since August 30, with an intermission of three weeks only, and that this seemed to be far from the actual limits of durability. When the currents employed are not too strong, the lamps will last longer. The light yielded by these lamps varies, according to circumstances, from thirty to fifty standard candles. On the occasion of Mr. Swan's lecture thirty-six of these tiny lamps were exhibited working by the current of a dynamo-electric machine requiring four horse-power to drive it. In the debate which followed Mr. Swan's communication, the remarks made by Prof. Tyndall, Dr. Hopkinson, Mr. Alexander Siemens, and others, showed the real value of the advance made by Mr. Swan. The question however of the economy of the system remains yet to be decided by the practical test of durability. At a previous lecture at Newcastle-on-Tyne Mr. Swan exhibited twenty lamps fed by a current generated by a gas-engine consuming 160 cubic feet of gas per hour. The light obtained exceeded that of the seventy gas-jets which usually sup. plied the same room, and which consumed 280 feet per hour. Mr. Swan proposes to connect these lamps in series of fifty or a hundred in one circuit, using automatic circuitclosers to close the circuit in the rare case of the failure of a lamp. He considers his method of arranging the system to be superior to that proposed by Mr. Edison, whose method of placing the separate lamps in single branches of a divided circuit would involve the use of very heavy and costly conducting-wires without any counterbalancing advantage. With this important difference Mr. Swan's further proposal to erect central stations from which to supply currents of electricity over large areas resembles that suggested by Mr. Edison. Should the anticipations of the inventor and the present promise of the new lamps be fulfilled, domestic electric lights will certainly become a fact at no distant date.

Meantime Mr. Edison has not been idle. It is stated that he is at present laying down a service of about seven miles in length upon which to test the success or failure of his system upon a large scale. He has developed several ideas since his last appearance before public notice. He now makes his dynamo-electric generators of a much larger pattern than any heretofore attempted. $\mathrm{He}$ has abandoned charred cardboard in favour of a filament of carbon prepared from a cultivated variety of the Japanese bamboo. We shall hear before long whether his indomitable perseverance has been rewarded with final success. In spite of being in point of date behind Mr. Swan, he has the enormous advantages of a unique workshop and laboratory under his own direction, of a wealthy company at his back, and of the extraordinary prestige won by his previous inventions. If Mr. Swan appears to be nearer to a genuine success, Mr. Edison has a popular reputation that of itself will win a hearing for the most trivial of his inventions. Whichever of the rival systems succeeds science and mankind are the gainers. But up to the present point it seems to us that beyond question Mr. Swan is nearer the goal of practical results than his famous rival.

It may interest our readers to know that Mr. Edison's first carbon lamp is now on view along with his original phonograph and his earliest tasimeter in the Patent Museum at South Kensington.

\section{SUBTERRANEAN FOREST IN INDIA}

THE accompanying notes and illustrations on the underground forest recently discovered in excavating the Prince's Dock, Bombay, were forwarded by Col. C. J. Merriman, R.E., C.S.I., Member of the Legislative Council, and Secretary to Government (Public Works Department), Bombay.

The trees were generally found in a dark loamy soil composed of underlying rock disintegrated. The upper

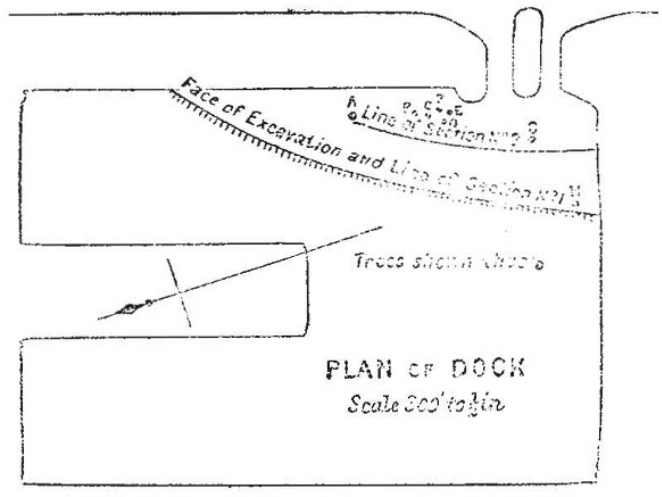

Fig. x.-Dock.

portion of the trunks stopped at the soft black clay, which is silt. A few went a little way beyond; but as far as they protruded into the silt they were completely

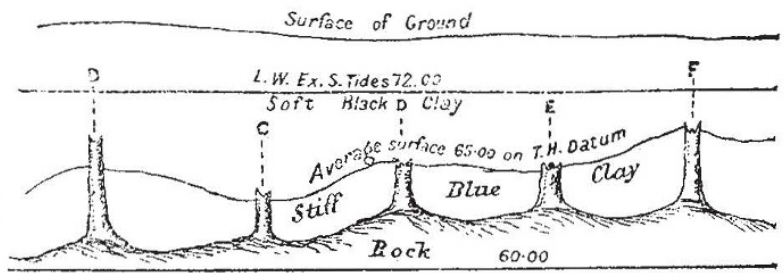

Fig. 2.-Section in line of trees B to F. Scale $i^{3}$ inch to $\mathrm{I}$ foot.

riddled by the teredo, the nearer the root the bigger the bole, showing that the boring began from the top.

The roots of the highest tree found were at $72^{2} 20$ on T.H. datum, or close on Low Water extreme springs, about six feet under the surface of the mud. The lowest root was 
at $55^{\circ} 93$, or say sixteen feet under L.W. extreme springs, twenty-two feet under the surface of the mud.

Inside the dock altogether were 382 trees, 223 standing, the remainder flat. The largest tree was forty-six feet

Copirs Lovel S:00

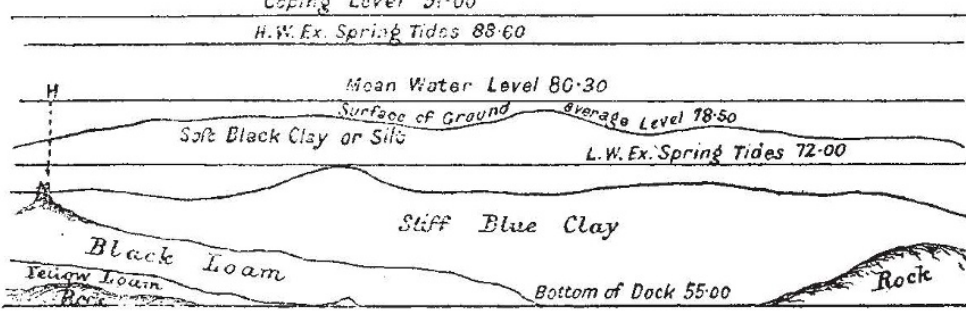

Fig. ${ }_{3}-$ Section No. x. Scale-Vertical 15 feet to $\frac{1}{2}$ inch, horizontal 150 feet to $\frac{x}{2}$ inch. long, and $4^{\prime} 6^{\prime \prime}$ girth; it was flat. None of the trees would girth over $4^{\prime} 6^{\prime \prime}$. The soil in which many of them stood was only $6^{\prime \prime}$ to $9^{\prime \prime}$ thick over the rock. The wood is apparently black wood. The roots presented a peculiar appearance, being nearly at right angles to the trunks.

The forest seems to have stopped at the gates, as very few trees were brought up in the dredging operations.

\section{NOTES}

Prof. Helmholtz has been appointed Faraday Lecturer for $188 \mathrm{I}$; the lecture will be given early in April.

WE greatly regret to announce the death of Sir Benjamin C. Brodie, Bart., F.R.S., the eminent chemist and late Professor of Chemistry in the University of Oxford. He died on Wednesday, last week, at Torquay, in the sixty-fourth year of his age. We hope to be able to give a detailed notice of Sir Benjamin's life and work in a future number.

THE death, on Sunday, is announced of Mr. Mark Firth, at Sheffield, in the sixty-second year of his age. Mr. Firth was eminent for his discriminating liberality, and will be specially known to our readers as the founder of the well-known Firth College, Sheffield, opened by Prince Leorold last year.

Prof. J. Charles D'Almeida, whose sudden death at Paris we mentioned a fortnight since, was one of the prominent leaders in the scientific circles of the French capital. Formerly a Pro. fessor of Physics in the Lyceum of Henry IV., he had occupied for some years past the important and responsible position of Inspector-General of Public Instruction. A strong Liberal in matters of education, he exercised a marked influence in the late reorganisation of the French educational system. It was almost entirely owing to his efforts that the Société Française de Physique owes its creation, and since its origin he has occupied the post of secretary. As an investigator D'Almeida is best known by his valuable researches on the phenomena of electrolysis, on galvanic batteries, on capillary phenomena, \&c. One of the most remarkable services he has rendered was the invention of the photographic despatches by means of which, during the siege of Paris, the inhabitants of the city were enabled to avail themselves so extensively of the otherwise limited services of the "pigeon post."

A SHORT time ago we alluded to the severe loss to chemical and technical literature by the death of Prof. von Wagner, who for twenty-five years past has conducted so ably his admirable Jahresbericht fiir die chemische Technologie. The difficult question of finding a successor in the editorship of this important annual has been happily solved by the choice of Dr. Ferd. Fisher, Professor of Technology at the Polytechnic of Hanover. For a long time past Prof. Fisher has rendered valuable literary services in editing Dingler's Polytcchnisches foumal, the most
The mixture of different kinds of stone is curious. In small patches we find trap, which gives way to moorum, and then a sort of pudding-stone mixed up with black and red stuff so hard that it cuts the divers' hands as with a knife.

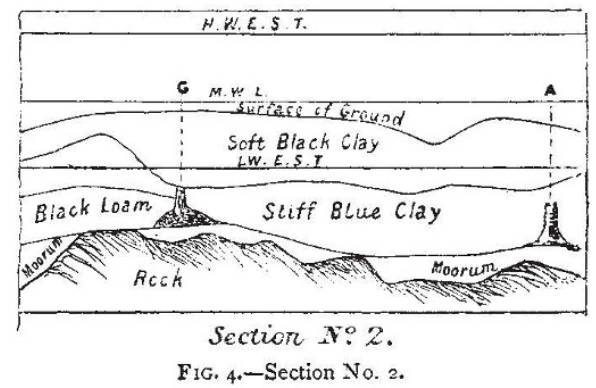

important technical publication on the Continent. As an in vestigator he is also well known by his elaborate researches on water in its technical and physiological relations, on pyrometry, and on numerous other chemical and technical questions. Under the new auspices the Fahrcsbericint has every reason to look forward to a continuance of its successful career.

M. Charcot reopened last week his course of botany at Salpetrière, where he exhibited last year the curious phenomena of female patients suffering from neuro-mental affections. New instances will be produced of cures analogous to the troubles regarded in mediæval times as produced by demoniacal agency or cured by witchcraft.

IN a lecture on earthquakes delivered in Vienna on the 22nct inst., Prof. v. Hochstetter designated the Agram earthquake (affecting elliptically a region of 60 to 80 German miles diameter, and having its larger axis directed south-south-west to northnorth-east) as a tectonic or dislocation-earthquake-a name which originated with the Austrian geologist Prof. Hörnes. Prof. Suiss expressed a similar opinion in a lecture on November 24, "On Earthquakes in the Alps."

ON Sunday evening, about six o'clock, slight shocks of earthquake were felt at two different places in Scotland-one being Callander, in Perthshire, and the other Inverary, in Argyllshire. The two districts affected are about forty miles apart, in a line due east and west. The shock was also felt at Rothesay and Stornoway. In the north of Ireland during Sunday evening and also the earlier hours of yesterday morning several decided shocks of earthquake were felt, especially in Londonderry and its vicinity. The disturbance was more particularly felt at Innishowen, and it seemed to travel across the bed of the River Foyle to the County Derry side, where the effects were felt strongly.

At DoRTMund there was a slight shock of earthquake on November 25, and a smart one on the 27 th.

Mr. MUNDElla has been speaking on education again, repeating essentially the old story, that our country must lose in the race unless, as in other countries, education in science is made an imperative part of elementary education. We have many natural and traditional advantages over other countries, but all these must in the long run succumb to scientific training.

A MAGNIFICENT lacustrine find has been made in the marshes of Corcelletes, near Consise, in Canton Vaud. It consists of $a$ 